\title{
Tuberculous morbidity in Swiss albino mice immunized with BCG*
}

\author{
By RICHARD COSTELLO AND SARA C. SLATS
}

The Rockefeller University, New York, New York 10021

(Received 8 June 1970)

\section{SUMMARY}

Study was made of the effect of BCG vaccination on the establishment of experimental tuberculous infection in mice. To this end, mice were infected with small quantities of virulent human bacilli administered by the respiratory route. The quantity of bacilli present for inhalation was so controlled as to permit only a finite percentage of unvaccinated animals to become infected. The relative proportion of mice infected by inhaling these small numbers of virulent bacilli was not found to be lowered by prior BCG vaccination. Thus, pulmonary tissue of immunized mice was not able to prevent the initial lodgement of virulent tubercle bacilli. The growth of virulent organisms in infected lungs, however, was significantly retarded by prior vaccination.

\section{INTRODUCTION}

$B C G$ vaccination increases resistance to tuberculosis both in experimental animals and in man. In experimental animals this enhanced resistance is manifested as an alteration of the progress of disease or as a delay in the onset of tuberculous mortality (Dubos, Pierce \& Schaefer, 1953). Contrariwise in man, vaccination decreases the primary incidence of tuberculous infection as well (Medical Research Council, 1963). Thus, human pulmonary tissue appears capable of acquiring greater immunity to tuberculosis than does similar tissue from lower mammals.

The evidence bearing on this question, however, is largely of an indirect nature. It has been found, for example, that similar numbers of bacilli are present in lungs of vaccinated or unvaccinated mice immediately after virulent infection (Conge, Collin, Levy \& Dubos, 1959). Equivalent numbers of organisms are also recovered from lungs of animals in both groups for many days after challenge. Moreover, a given infection produces identical numbers of pulmonary lesions in animals irrespective of whether they are vaccinated or not (Levy et al. 1961). Thus, in the case of mice, the resistance acquired by vaccination does not appear capable of greatly influencing the host's initial response to virulent challenge.

Recent studies in this laboratory show that this question may be approached more directly. Thus, animals may be consistently exposed to a respiratory infec-

* This investigation was supported in part by the United States-Japan Cooperative Medical Science Programme administered by the National Institute of Allergy and Infectious Diseases of the National Institutes of Health, Department of Health, Education and Welfare. 
tion composed of only a few virulent organisms. Under these conditions only a small number of untreated mice become infected. Thus, mice may be experimentally challenged under conditions analogous to those occurring in natural human infection. This technique makes it possible to test exactly whether the incidence of infection is significantly lowered by prior BCG vaccination.

The incidence of tuberculous infection was found to be identical in control and immunized mice. Hence, BCG vaccination did not appear to enhance the ability of mice to prevent the initial establishment of even a small number of virulent bacilli in their pulmonary tissue.

\section{MATERIALS AND METHODS}

The materials and methods used here have been described previously (Costello, Dubos \& Schaedler, 1962; Costello, Hedgecock \& Hamilton, 1962).

\section{Animals}

The NCS strain of Swiss mice was used in all phases of the study (Nelson \& Collins, 1961). Female animals were obtained when 5-6 weeks old and used immediately. Animals were maintained on a commercial pellet diet ( $D \&$ G pellets, Dietrich \& Gambrill, Inc., Frederick, Md.) with unlimited access to tap water.

\section{Vaccination}

The Montreal Strain of BCG was obtained from the Institute of Hygiene, University of Montreal.* The vaccine was received in the lyophilized state and was used without subculture. Ampoules containing $118 \mathrm{mg}$. of freeze-dried bacilli were reconstituted with $50 \mathrm{ml}$. of albumin water. Samples of the reconstituted material were stored at $-60^{\circ} \mathrm{C}$. in a technique similar to that described by Grover, Kim, Wiegshouse \& Smith (1967). A tenfold dilution of the thawed vaccine was made before use and $0.2 \mathrm{ml}$. of the resulting suspension intraperitoneally injected into individual mice. Animals were vaccinated when received and 10 weeks later they, together with comparable untreated mice, were challenged with virulent mycobacteria.

\section{Challenge}

The $\mathrm{H} 37 \mathrm{Rv}$ strain of Mycobacterium tuberculosis was originally obtained from The Trudeau Institute, Saranac Lake, New York. Subcultures were made in Kirchner's medium containing Tween 80 and bovine serum albumin. Before use, the growth from a 5-day culture was homogenized in a teflon-glass tissue grinder for $1 \mathrm{~min}$. and the resulting suspension filtered through a $5 \mu$ porosity Millipore filter. This filtered material was found to consist primarily of single bacilli suitable for aerosol administration. The number of living bacilli present in the infective material was determined at this time and again at the time of challenge infection. Material sufficient for all challenge infections was prepared at the same time. Samples were stored at $-60^{\circ} \mathrm{C}$. until use. Immediately before use, a sample was removed from

* The authors are indebted to Dr Frappier of the Institute of Hygiene for making large quantities of vaccine available for this study. 
storage, thawed and serial tenfold dilutions were made with albumin water in order to obtain the desired number of virulent organisms $/ \mathrm{ml}$.

Animals were infected in a Middlebrook type aerosolization chamber (Tri R Instrument Corporation, Rockville Centre, N.Y.) (Izumi, Costello \& Dubos, 1969). The infection induced by nebulization of different quantities of organisms was determined in initial experiments which are detailed in the experimental section. Generally speaking, $10 \mathrm{ml}$. of infectious material was nebulized over a 60-min. period. The rate of infectious air flow was held constant at $20 \mathrm{l} / \mathrm{min}$. Following nebulization of the infective inocula, the aerosol cloud was allowed to decay for $30 \mathrm{~min}$. and the chamber decontaminated with UV light for a further 15-min. period.

For the experimental tests, vaccinated mice were marked and mixed with untreated mice before being placed in the infection basket of the aerosol chamber. Sixty mice were exposed to infection at one time. Following airborne exposure, the animals were removed, resegregated, and maintained in separate groups until killed.

\section{Enumeration of organisms from lungs of mice}

Unless otherwise indicated, mice were killed 4 weeks after infection. At this time the animal's lungs were aseptically removed and homogenized in $2 \%$ bovine serum albumin water with the aid of a teflon-glass tissue grinder. Serial tenfold dilutions were made in albumin water. Equal volumes of each dilution were transferred to sterile screw cap tubes to which $2 \mathrm{ml}$. of base medium* containing $0.2 \%$ agar was added. The tubes were incubated at $37^{\circ} \mathrm{C}$. and the number of colonies which developed was determined after 3 weeks incubation.

Separation of the organisms of challenge from those of vaccination was accomplished by use of the differential inhibitor 2-thiophene-carboxilic acid hydrazide. The inhibitor, in water, was sterilized by filtration and added to the soft agar medium in a final concentration of $15 \mu \mathrm{g} . / \mathrm{ml}$.

\section{Standardization of experimental conditions}

Establishment of a reproducible infection was crucial to the experimental work described. The inoculum for nebulization was carefully standardized. The rate of nebulization and the flow of infectious air were kept constant. The same venturi apparatus was used for nebulization in all experiments. The animals used were of the same age and sex.

When these and like conditions were uniformly maintained, the dose of organisms required to induce pulmonary infection in some, but never all of the exposed animals was readily established. Moreover, these conditions could be reproduced at will.

* A base medium of the following composition was used in these experiments: $\mathrm{Na}_{2} \mathrm{HPO}_{4}$. $12 \mathrm{H}_{2} \mathrm{O}, 3.0 \mathrm{~g}$.; $\mathrm{KH}_{2} \mathrm{PO}_{4}(\mathrm{Anh}), 4 \cdot 0 \mathrm{~g}$; ; sodium citrate. $\mathrm{H}_{2} \mathrm{O}, \mathrm{I} \cdot 0 \mathrm{~g}$.; ferric ammonium citrate (USP grade), $0 \cdot 1 \mathrm{~g}$; $\mathrm{MgSO}_{4} \cdot 7 \mathrm{H}_{2} \mathrm{O}, 0 \cdot 1 \mathrm{~g}$; ; bacto asparagine, $2 \cdot 0 \mathrm{~g}$.; bacto tryptone, $5 \cdot 0 \mathrm{~g}$.; bacto agar, $2.0 \mathrm{~g}$.; glycerin, $10 \cdot 0 \mathrm{ml}$; $\mathrm{H}_{2} \mathrm{O}$, to $1000 \mathrm{ml}$.

The following additions were made to each $100 \mathrm{ml}$. of melted medium prior to use: penicillin $(10,000 \mathrm{unit} / \mathrm{ml}$.), $0.1 \mathrm{ml}$; lysozyme $(0.1 \%$ in $0.01 \mathrm{~N}-\mathrm{HCl}), 1.0 \mathrm{ml}$; bovine serum, $10 \cdot 0 \mathrm{ml}$. 
The results described were obtained in a number of different experiments. Since large groups of animals were used and since the results were remarkably consistent and reproducible, a high degree of confidence can be attached to them.

\section{RESULTS}

\section{Exposure of mice to small doses of mycobacteria}

The minimum quantity of mycobacteria required to initiate pulmonary tuberculous infection in mice was determined as follows.

In a typical experiment 6-week-old female mice were obtained and distributed into several large groups. Each group of animals was exposed to aerosol infection with a diminishing number of virulent human bacilli. To this end, serial tenfold dilutions of the suspension of virulent mycobacteria were made in albumin water. At successive times, individual groups of animals were exposed to the aerosol produced by nebulizing $10 \mathrm{ml}$. of each dilution. Thus, the first group of animals was exposed to the aerosol obtained from the most diluted suspension. After decontamination of the chamber these animals were removed and the second group of mice was exposed to aerosol infection with the next highest dilution and so forth. The last group of mice was exposed to the aerosol obtained by nebulization of the undiluted suspension. Five mice from each group were killed at various intervals following challenge and the numbers of organisms present in their lungs were determined. The results of this experiment are detailed in Tables 1 and 2.

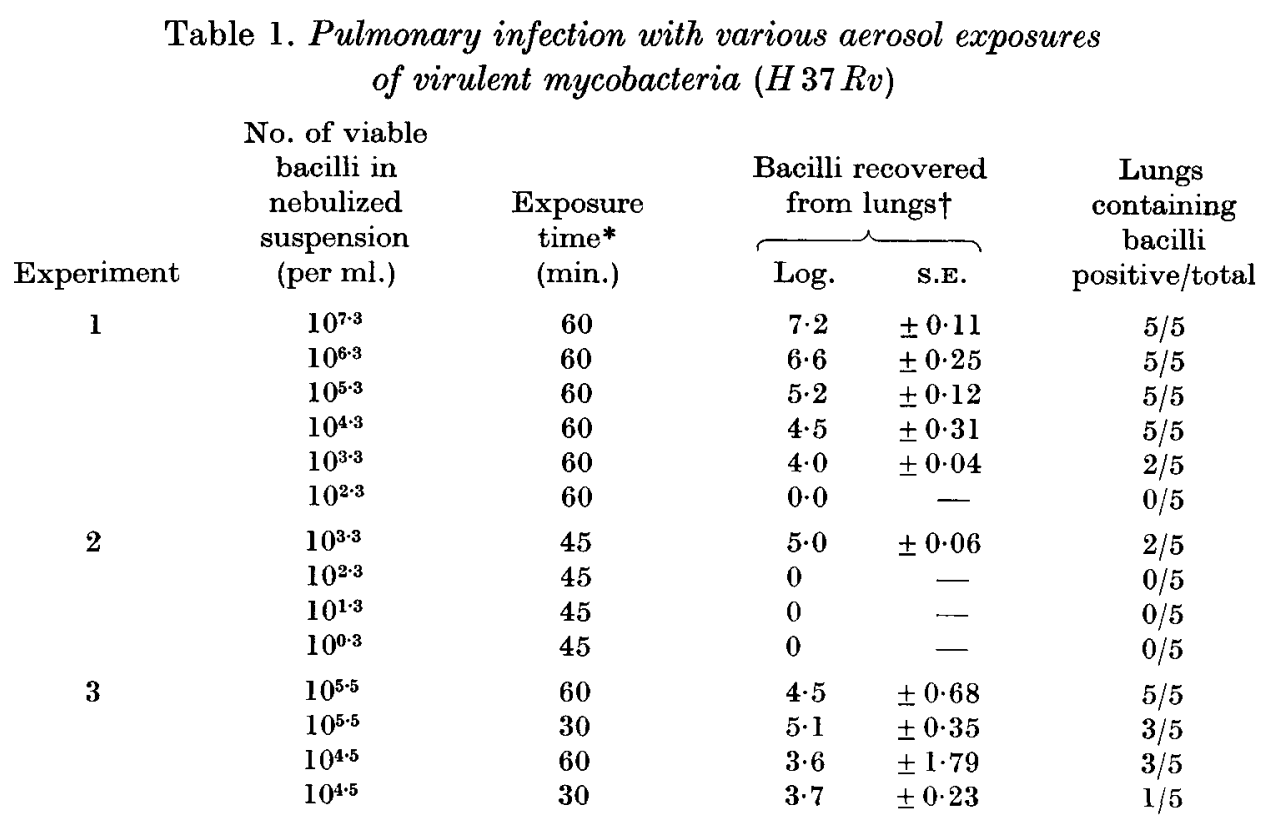

* The volume of suspension nebulized was approximately $9.9 \mathrm{ml} . / \mathrm{hr}$. for Expt. no. 1; $7.5 \mathrm{ml} . / 45 \mathrm{~min}$. for Expt. no. 2 ; and 9.4 ml./hr. for Expt. no. 3.

$\dagger$ Number of virulent mycobacteria (expressed as logs) recovered from lungs 4 weeks after challenge infection \pm standard error of mean. Values are for 1 cc. of lung homogenate (out of a total $5 \mathrm{cc}$.). Only positive values (i.e. of lungs containing mycobacteria) are included in average. 
In other experiments the incidence of infection in mice exposed to the aerosol mist for shorter intervals of time was determined. The same technical conditions were maintained in these experiments as in those just described. These results are also given in Tables 1 and 2.

Table 2. Challenge organisms recovered from lungs of untreated mice following aerosol exposure to virulent mycobacteria

\begin{tabular}{|c|c|c|c|c|c|c|}
\hline $\begin{array}{c}\text { Experi- } \\
\text { ment }\end{array}$ & $\begin{array}{l}\text { No. of } \\
\text { viable } \\
\text { bacilli in } \\
\text { nebulized } \\
\text { suspension } \\
\text { (per ml.) }\end{array}$ & $\begin{array}{l}\text { Ex- } \\
\text { posure } \\
\text { time } \\
\text { (min.) }\end{array}$ & $\begin{array}{c}\text { Time } \\
\text { between } \\
\text { challenge } \\
\text { and } \\
\text { sacrifice } \\
\text { (wks.) }\end{array}$ & $\begin{array}{c}\text { Mycobacteria } \\
\text { recovered from } \\
\text { lungs of } \\
\text { individual animals* } \\
\text { (log.) }\end{array}$ & $\begin{array}{l}\text { Group } \\
\text { average } \\
\text { (log.) }\end{array}$ & $\begin{array}{l}\text { No. of lungs } \\
\text { containing } \\
\text { mycobacteria } \\
\text { positive/total }\end{array}$ \\
\hline \multirow[t]{3}{*}{$\mathbf{I}$} & $10^{4 \cdot 3}$ & 60 & $\begin{array}{r}1 \\
2 \\
4 \\
10 \\
20 \\
40\end{array}$ & $\begin{array}{l}1 \cdot 3,1 \cdot 5,1 \cdot 5,1 \cdot 8,1 \cdot 9 \\
3 \cdot 5,3 \cdot 5,3 \cdot 5,3 \cdot 7,- \\
3 \cdot 5,4 \cdot 0,5 \cdot 0,5 \cdot 0,5 \cdot 0 \\
5 \cdot 9,6 \cdot 0,6 \cdot 3,6 \cdot 7,7 \cdot 0 \\
5 \cdot 7,7 \cdot 0,7 \cdot 6,8 \cdot 0,8 \cdot 7 \\
7 \cdot 0,7 \cdot 0,9 \cdot 3,11 \cdot 0,11 \cdot 0\end{array}$ & $\begin{array}{l}1 \cdot 6 \\
3 \cdot 5 \\
4 \cdot 5 \\
6 \cdot 3 \\
7 \cdot 4 \\
9 \cdot 0\end{array}$ & $\begin{array}{l}5 / 5 \\
4 / 4 \\
5 / 5 \\
5 / 5 \\
5 / 5 \\
5 / 5\end{array}$ \\
\hline & $10^{3 \cdot 3}$ & 60 & $\begin{array}{r}1 \\
2 \\
4 \\
10 \\
20 \\
40\end{array}$ & $\begin{array}{l}0,0,0,0 \cdot 3,0 \cdot 5 \\
0,2 \cdot 5,2 \cdot 8,3 \cdot 3,3 \cdot 3 \\
0,0,0,3 \cdot 9,4 \cdot 0 \\
0,0,0,4 \cdot 0,5 \cdot 7 \\
0,5 \cdot 6,5 \cdot 9,6 \cdot 9,7 \cdot 5 \\
0,0,5 \cdot 9,6 \cdot 3,8 \cdot 5\end{array}$ & $\begin{array}{l}0 \cdot 4 \\
3 \cdot 0 \\
4 \cdot 0 \\
4 \cdot 8 \\
6 \cdot 5 \\
6 \cdot 9\end{array}$ & $\begin{array}{l}2 / 5 \\
4 \cdot 5 \\
2 / 5 \\
2 / 5 \\
4 / 5 \\
3 / 5\end{array}$ \\
\hline & $10^{2 \cdot 3}$ & 60 & $1-10$ & $0,0,0,0,0$ & - & All $0 / 5$ \\
\hline 2 & $10^{3 \cdot 3}$ & 45 & $\begin{array}{r}1 \\
2 \\
4 \\
10\end{array}$ & $\begin{array}{l}0,0,0,0 \cdot 1,0 \cdot 3 \\
0,0,0,0,0 \\
0,0,0,4 \cdot 5,5 \cdot 6 \\
0,0,0,0,6 \cdot 0\end{array}$ & $\begin{array}{l}0 \cdot 2 \\
\frac{-}{5 \cdot 0} \\
6 \cdot 0\end{array}$ & $\begin{array}{l}2 / 5 \\
0 / 5 \\
2 / 5 \\
1 / 5\end{array}$ \\
\hline & $10^{2 \cdot 3}$ & 45 & $1-10$ & $0,0,0,0,0$ & - & All $0 / 5$ \\
\hline
\end{tabular}

* Number of virulent mycobacteria (expressed as logs) recovered from individual lungs after challenge infection. See Table 1 for explanation.

The first experiment described in Table 1 illustrates the type and severity of infection which occurred in animals following exposure to aerosols of different bacterial densities. The results presented in this table indicate the proportion of animals which contracted infection and the number of organisms recovered from their lungs 4 weeks after challenge.

Infection occurred in all animals exposed for $60 \mathrm{~min}$. to aerosols produced by nebulizing suspensions containing from $10^{7.3}$ to $10^{4 \cdot 3} \mathrm{bacilli} / \mathrm{ml}$. The number of bacilli recovered from the lungs was roughly proportional to the size of the infective inoculum. In contrast, only two out of five animals exposed to $10^{3 \cdot 3}$ bacilli/ $\mathrm{ml}$. showed organisms in their lungs and none of those exposed to the next higher dilution were infected. The minimal infective dose, established in this manner, is defined as the number of bacilli which, when nebulized under standardized conditions, causes infection in some but not all of the animals exposed to it.

The second experiment described in Table 1 presents the results of a similar although independent experiment. Dilutions of the same frozen stock of challenge 
organisms were used. Animals were exposed to the aerosol for 45 min. instead of $1 \mathrm{hr}$. Again in this experiment, some of the animals exposed to the aerosolization of $10^{3.3} \mathrm{bacilli} / \mathrm{ml}$. became infected while no animals were infected when exposed to $10^{2 \cdot 3}$ or fewer mycobacteria.

Fewer animals exposed to this shorter length of challenge were infected; this may be seen better in Table 2, where the results of the two experiments are described in greater detail. It is worth noting, however, that the number of organisms present in the lungs of infected animals in experiment two was as high, or indeed, slightly higher, than in infected mice in the first experiment.

The results detailed for experiment three in Table 1 further illustrate that the infectivity of small doses of mycobacteria administered by the respiratory route depends not only on the number of infective particles in the aerosol cloud but also on the length of time that the animals are exposed to it. Thus, as is shown by the results of this experiment, aerosols of suspensions which infected all mice when nebulized for $1 \mathrm{hr}$. were able to infect only some animals when the length of exposure was decreased to $30 \mathrm{~min}$. Similarly, a serial dilution of this suspension infected some animals when it was administered for $1 \mathrm{hr}$. but was only sporadically infective when the length of exposure was shortened.

The results given in Table 2 illustrate these points in greater detail. In this table the sequential course of infection is followed in animals exposed to moderate and minimal respiratory tubercular challenge. For illustrative purposes, the actual number of bacilli (in logs) recovered from each animal's lung at various times after challenge is given.

It may be observed that all animals exposed to aerosols obtained by nebulization of a moderate number of bacilli $\left(10^{4 \cdot 3} \mathrm{bacilli} / \mathrm{ml}\right.$.) were infected. The pulmonary infection progressed in a uniform manner in these mice with increasingly large numbers of virulent organisms being recovered from the animal's lungs at every test period.

In contrast, only some $60 \%$ of the mice exposed to the smaller challenge dose became infected. The proportion of infected to non-infected animals present was found to be similar at all intervals of time after infection. This finding, i.e. that the relative number of animals whose lungs were infected did not increase with time, is of especial importance, since it suggests that retarded or delayed pulmonary infection did not occur in any significant number of animals.

The growth of organisms in the lungs of these infected mice progressed at approximately the same rate as it did in the tissues of mice infected by heavier aerosol exposure. Thus, only small numbers of organisms were present in infected lungs the first week after challenge. Four weeks later, extensive multiplication of the virulent mycobacteria had occurred in these lungs and the infected animals were readily distinguishable from their non-infected cage mates.

\section{Incidence of infection in $B C G$ vaccinated mice}

The effect of BCG immunization on infectious morbidity was studied in mice vaccinated by peritoneal administration of living BCG.

The in vivo growth of the vaccine was determined in preliminary experiments. 
Six-week-old female NCS mice were obtained and different groups of animals were injected with one of several dilutions of vaccine. At intervals thereafter, five animals of each group were killed and the number of BCG bacilli contained in their organs determined.

Both spleens and lungs of animals injected with heavier doses of vaccine were immediately infected and large numbers of bacilli were subsequently recovered from either organ. In all experiments described animals were injected with $10^{5.7}$ BCG bacilli/mouse. Ten weeks after injection of this dose of vaccine, the lungs of immunized animals still retained culturable vaccine bacilli, although in low number, and their spleens contained an average of $10^{3.8}$ bacilli. These animals were found to be highly immune as measured by resistance to the pulmonary growth of virulent mycobacteria given by the respiratory route, and to intravenous injection of massive quantities of human bacilli.

Large numbers of mice were used in the main vaccination experiments. For this purpose, 6-week-old mice were obtained and divided into two groups. One group of animals received $0.2 \mathrm{ml}$. of BCG vaccine by peritoneal injection; the other group was left untreated. Exactly 10 weeks after immunization, animals of both groups were exposed to aerosol challenge infection. For this purpose vaccinated and nonvaccinated mice were mixed, placed in the aerosol chamber and exposed to the respiratory challenge infection previously found (see above) to infect some but not all of the untreated animals. Animals were killed 4 weeks after challenge infection and the number of virulent bacilli present in their lungs determined. This same procedure was repeated at weekly intervals. The results of several typical experiments are presented in Tables 3 and 4.

The actual numbers of mycobacteria present in samples of lung tissue homogenate in a representative experiment are given in Table 3 . The experimental groups in this case consisted of ten untreated and ten vaccinated mice. Animals were killed 4 weeks after challenge infection. Their lungs were removed, homogenized and the numbers of virulent organisms present in the homogenate determined.

As may be seen, one-half of the untreated animals were infected during the challenge exposure. Large numbers of bacilli were recovered from all dilutions of homogenate of these infected lungs. No organisms were recovered from the lungs of the remaining five animals.

Similarly, four out of the ten vaccinated animals acquired infection from exposure to the challenge aerosol. Organisms were found only in the lower dilutions of lung homogenate of these mice. Thus, significantly fewer organisms were present in the infected lungs of vaccinated mice than were recovered from lungs of nonimmunized control animals.

The effect of prior BCG vaccination on the incidence of pulmonary infection by small numbers of virulent bacilli is further detailed in Table 4 where the results of three successive experiments are illustrated.

It may be seen that the same relative number of vaccinated or unvaccinated animals were infected in each experiment. The rate of infection of untreated animals varied in the three experiments from a high of $95 \%$ to a low of $38 \%$, 
probably due to slight, although indeterminate, variations in technical conditions.

It is apparent that the resistance acquired by vaccination with BCG had little significant effect on the animal's ability to prevent establishment of the organisms of challenge within their pulmonary tissue. However, vaccination retarded the progress of the pulmonary infection even though it did not prevent its initial establishment.

Table 3. Organisms present in lungs of normal and BCG vaccinated animals after minimal infective challenge

Organisms recovered from lungs of individual mice*

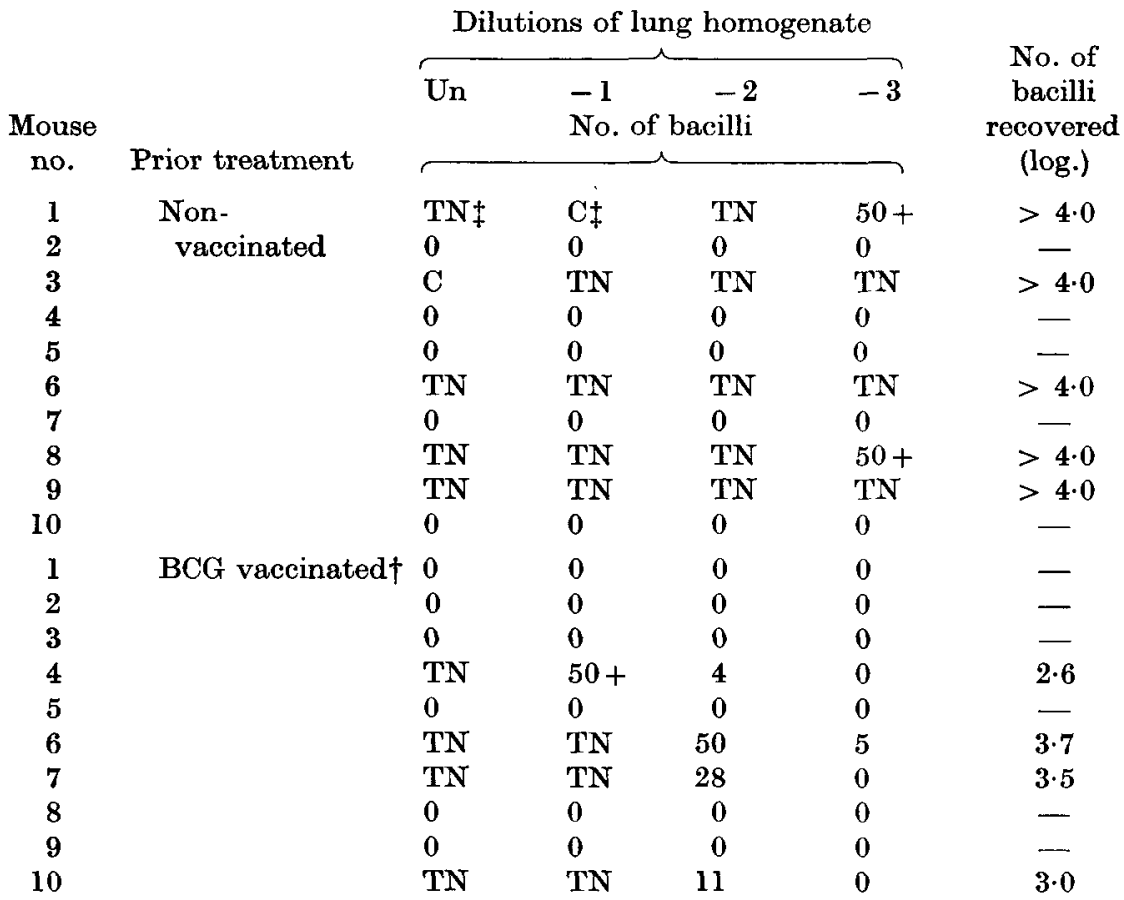

* Number of virulent mycobacteria recovered from individual mice 4 weeks after challenge. Challenge infection was produced by nebulization of $10 \mathrm{ml}$. suspension containing $10^{3 \cdot 3}$ bacilli $/ \mathrm{ml}$. over a $60-\mathrm{min}$. period. Values refer to actual number of bacilli present in $1 \mathrm{cc}$. of lung homogenate (out of a total of $5 \mathrm{cc}$.) or of $1 \mathrm{cc}$. of each serial dilution of this suspension.

$\dagger$ Animals were peritoneally injected with $0.2 \mathrm{ml}$. of Montreal strain BCG 10 weeks prior to challenge. Individual animals received $0.047 \mathrm{mg}$. of vaccine containing $10^{5 \cdot 7}$ cultivable bacilli.

$\ddagger T N$ indicates value too numerous to count; $C$ indicates contaminated sample.

It is of interest to compare the relative retardation of bacterial growth in lungs of vaccinated animals infected with a minimum number of virulent bacilli with those of animals infected by aerosol exposure to infective clouds containing approximately 100 times as many virulent bacilli. Experiments, not to be detailed here, have shown that 4 weeks after challenge infection the lungs of heavily infected vaccinated animals contain $c a, 1 \cdot 2-1 \cdot 6 \mathrm{log}$. fewer organisms than lungs of 
unvaccinated mice. In a typical experiment, for example, animals were infected with an aerosol produced by nebulizing $10^{5.5}$ virulent bacilli. Lungs of unvaccinated mice were found to contain an average of $10^{6.0}$ virulent bacilli when tested 4 weeks after challenge, whereas lungs of BCG vaccinated mice infected at the same time contained an average of $10^{4.6}$ virulent organisms. This relative difference is essentially the same as that found in the experiments described in Table 4.

\section{Table 4. Incidence of infection of normal or BCG vaccinated mice when exposed to small numbers of virulent mycobacteria}

\begin{tabular}{|c|c|c|c|c|c|c|c|}
\hline \multirow{2}{*}{$\begin{array}{c}\text { Experi- } \\
\text { ment }\end{array}$} & \multirow{2}{*}{$\begin{array}{c}\text { Vacci- } \\
\text { nation* }\end{array}$} & \multirow{2}{*}{$\begin{array}{c}\text { No. of } \\
\text { viable } \\
\text { bacilli in } \\
\text { nebulized } \\
\text { suspension }\end{array}$} & \multirow{2}{*}{$\begin{array}{c}\text { No. of } \\
\text { animals } \\
\text { challenged }\end{array}$} & \multicolumn{2}{|c|}{$\begin{array}{c}\text { Animals with } \\
\text { infected lungs }\end{array}$} & \multicolumn{2}{|c|}{$\begin{array}{c}\text { Organisms } \\
\text { recovered from } \\
\text { infected lungs } \dagger,\end{array}$} \\
\hline & & & & No. & Per cent & Log. & s.E. \\
\hline 1 & - & $10^{3 \cdot 3}$ & 20 & 19 & 95 & $3 \cdot 9$ & \pm 0.23 \\
\hline & $\mathrm{BCG}$ & $10^{3 \cdot 3}$ & 17 & 16 & 94 & $3 \cdot 1$ & \pm 0.19 \\
\hline 2 & $\overline{\mathrm{BCG}}$ & $\begin{array}{l}10^{3 \cdot 3} \\
10^{3 \cdot 3}\end{array}$ & 20 & $\begin{array}{l}15 \\
18\end{array}$ & $\begin{array}{l}75 \\
85\end{array}$ & $\begin{array}{l}4 \cdot 1 \\
3 \cdot 1\end{array}$ & $\begin{array}{l} \pm 0.19 \\
+0.10\end{array}$ \\
\hline 3 & $\overrightarrow{\mathrm{BCG}}$ & $\begin{array}{l}10^{3 \cdot 3} \\
10^{3 \cdot 3}\end{array}$ & $\begin{array}{l}13 \\
20\end{array}$ & $\begin{array}{l}5 \\
8\end{array}$ & $\begin{array}{l}38 \\
40\end{array}$ & $\begin{array}{l}4 \cdot 0 \\
3 \cdot 0\end{array}$ & $\begin{array}{r} \pm 0.39 \\
+0.20\end{array}$ \\
\hline
\end{tabular}

* Animals were peritoneally injected with $0.2 \mathrm{ml}$. of Montreal Strain BCG 10 weeks prior to challenge. Individual animals received $0.047 \mathrm{mg}$. of vaccine containing $10^{5-7}$ cultivable bacilli.

$\dagger$ Number of virulent mycobacteria (expressed as logs) recovered from lung 4 weeks after challenge infection \pm standard error of the mean. Values are for $1 \mathrm{cc}$. of lung homogenate (out of a total of $5 \mathrm{cc}$.).

$\ddagger P$ values comparing vaccinated to control groups for the three experiments are: Expt. no. 1 , $<0.02$; Expt. no. $2,<0.01$; Expt. no. 3, $<0.05$.

\section{DISCUSSION}

The results described in this paper give direct evidence that morbidity to respiratory tuberculosis is not significantly lowered in mice by vaccination with living BCG.

Other investigators have shown that the early pulmonary infection which occurs in immune and non-immune animals is quantitatively similar. Thus, it has been previously postulated that the initial establishment of tubercle bacilli within the lungs of mice would not be greatly influenced by the hosts' immune response (Levy et al. 1961). The results of the experiments described in this paper confirm these deductions. It should be pointed out that, in the study just quoted, relatively large infective inocula were used. Thus, any small protective capacities of the immunized animal were likely to have been overwhelmed by the organisms of challenge. That this consideration is without merit, however, is apparent from the results described here since in these experiments immunized pulmonary tissue was unable to prevent the establishment of the few, perhaps even single, infectious particles that were administered.

Although the primary lodgement of virulent bacilli in pulmonary tissue was not 
prevented by prior vaccination with BCG, the subsequent growth of the challenge organisms was sharply limited. The fact that significantly fewer challenge organisms were present in infected lungs of vaccinated animals at the time of testing is evidence that these mice had acquired a high degree of immunity.

The conditions of vaccination used in these experiments deserves comment. Larson \& Wicht (1962) found that the resistance attained by animals was materially affected by the route by which the vaccine was administered; this was not supported by our findings (Izumi et al. 1969). In this regard it should be pointed out that large quantities of BCG were administered in our experiments and, irrespective of the site of inoculation, large numbers of vaccine organisms were recovered from the spleen and lungs at the time of challenge. None the less, it is possible that mice vaccinated under other conditions may respond differently and that their pulmonary tissue would be able to inhibit, either partly or completely, the establishment of small infective inocula.

It should be emphasized, moreover, that our conclusions are necessarily valid only for Swiss strain mice and may have limited bearing on the responses of other experimental animals to tuberculous infection. Indeed, it is not unlikely that other species of animals may respond in an entirely different fashion. In this regard, it should be noted that epidemiological studies suggest that the primary incidence of tuberculous disease in humans may be greatly lowered by vaccination with BCG.

Finally, the small quantity of virulent bacilli required to induce infection in untreated mice merits brief comment. Albino mice are presumed to have a high innate resistance to infection with tubercle bacilli. This belief is largely based on the finding that massive quantities of virulent bacilli must be administered to these animals to eause mortality. There is reason to believe, however, that the actual resistance of mice to tuberculous infection is greatly overestimated. Thus, it has been found that splenic infection can be uniformly established in mice injected intraperitoneally with as few as $6 \pm 3$ culturable bacilli ( $R$. Costello \& S. C. Slats, data to be published). Furthermore, lungs of mice can be consistently infected following intranasal instillation of suspensions of mycobacteria so dilute that organisms are recovered only occasionally on their culture (Gray \& Mattinson, 1952). The results described in this present paper also suggest that lungs of mice are highly susceptible to respiratory infection. Thus, the aerosol obtained from nebulizing very dilute suspensions of virulent human bacilli can induce infection in at least some mice.

In this regard it is probably not possible to determine the exact number of bacilli inhaled by each animal during exposure to the small infective aerosol. From the number of bacilli present in the nebulized inocula, and the average nominal recovery values (Rosebury, 1947) as ascertained in separate experiments, however, it can be roughly estimated that animals exposed to the minimal infective aerosol (the quantity which caused infection of some but not all of the challenged mice) contacted between $\mathbf{0 \cdot 2}$ and 2 virulent organisms. With an infective dose of this small magnitude it is likely that some animals inhaled single infective particles whereas others were exposed to none. 
The results presented yield no direct evidence concerning the factors involved in vaccinal resistance to tuberculosis. It should not be presumed, however, from the failure of vaccinated animals either to prevent the establishment of tuberculous infection, or to prevent the pulmonary growth of virulent organisms, that the immune state which develops in mice is necessarily insignificant. It has been repeatedly demonstrated, for example, that $\mathrm{BCG}$ vaccination confers on mice a significant ability to limit the intraorgan spread and extrapulmonary growth of virulent bacilli. Furthermore, the average survival time of animals infected with virulent bacilli is greatly prolonged by prior $B C G$ vaccination. In mice, as in men, the most important effect of vaccination may be to retard the solemn progression of disease.

The authors are indebted to their colleague, Dr Takehiko Sakurami, for theoretical and technical assistance with the aerosol infection apparatus. This work was performed in the laboratories of Dr Rene Dubos.

\section{REFERENCES}

Conge, G., Collin, E., Levy, F.M. \& Dubos, R. J. (1959). Microscopic enumeration of mycobacteria in pulmonary lesions of tuberculous mice. Effect of prior BCG vaccination. American Review of Tuberculosis and Pulmonary Disease 79, 484.

Costello, R., Dubos, R. \& Schaedler, R. W. (1962). Measurement of resistance to experimental tuberculosis in mice. The hyperacute phase. Journal of Experimental Medicine 116, 847.

Costello, R., Hedgecock, L. W. \& Hamilton, T. R. (1962). Alteration of resistance of the rat to tuberculosis when maintained on an atherogenic diet. Journal of Experimental Medicine 116, 835.

Dubos, R. J., Pierce, C. H. \& Schaefer, W. B. (1953). Antitubercular immunity induced in mice by vaccination with living cultures of attenuated tubercle bacilli. Journal of Experimental Medicine 97, 207.

Gray, D. F. \& MatTinson, M. W. (1952). Detection of small numbers of tubercle bacilli from dispersed cultures, using mice, guinea pigs, and artificial media. American Review of Tuberculosis and Pulmonary Disease 65, 572.

Grover, A. A., Kim, H. K., Wiegshouse, E. H. \& Smith, D. W. (1967). Host-parasite relationships in experimental airborne tuberculosis. II. Reproducible infection by means of an inoculum preserved at $-70^{\circ} \mathrm{C}$. Journal of Bacteriology 94, 832 .

Izumi, T., Costello, R. \& Dubos, R. (1969). Development of pulmonary antitubercular immunity in mice. Abstract United States-Japan Fourth Annual Tuberculous Research Conference, September.

Larson, C. L. \& Wicht, W. C. (1962). Studies of resistance to experimental tuberculosis in mice vaccinated with living attenuated tubercle bacilli and challenged with virulent organisms. American Review of Respiratory Disease 85, 833.

Levy, F., Conge, G. A., Pasquier, J. F., Mauss, H., Dubos, R. J. \& Schaedere, R. W. (1961). The effect of BCG vaccination on the fate of virulent tubercle bacilli in mice. American Review of Respiratory Disease 84, 28.

Medicat Research CodNCIL (1963). BCG and vole bacillus vaccines in the prevention of tuberculosis in adolescence and early adult life. Third report to the Medical Research Council by their tuberculous vaccines clinical trials committee. British Medical Journal i, 973.

Nelson, J. B. \& Collins, G. R. (1961). The establishment and maintenance of a specific pathogen-free colony of Swiss mice. Proceedings of the Animal Care Panel 11, 65.

Rosebury, T. (1947). Experimental Air-Borne Infection. Baltimore: Williams and Wilkins Co. 